\title{
ASSESSMENT OF KNOWLEDGE, PRACTICE AND PERCEPTION OF NIGERIAN MEDICAL PRACTITIONERS ON COVID-19 AND ITS TREATMENT USING ANTIMALARIAL DRUGS
}

Oluwafunmibi Anjorin ${ }^{1}$, Olawunmi Oyerinde (nee Rabiu) ${ }^{2}$, Ikechukwu Orji ${ }^{3}$, Mercy Ikechukwu-Orji ${ }^{3}$, and Ibukun Anjorin ${ }^{4}$

${ }^{1}$ Babcock University

${ }^{2}$ Affiliation not available

${ }^{3}$ University of Abuja

${ }^{4}$ University College Hospital Ibadan

July 8, 2021

\section{Hosted file}

2021 - Assessment of Knowledge, Practice and Perception of Nigerian Medical Practitioners on COVID-19 a available at https://authorea.com/users/351575/articles/476154-assessment-of-knowledgepractice-and-perception-of-nigerian-medical-practitioners-on-covid-19-and-its-treatmentusing-antimalarial-drugs 